ks. Stanisław Szczepaniec

\title{
Celebracja liturgiczna po Soborze Watykańskim II
}

W 1985 roku Ojciec Święty Jan Paweł II zwołał II Nadzwyczajne Zgromadzenie Synodu Biskupów ${ }^{1}$. Okazją była 20. rocznica zakończenia Soboru Watykańskiego II. „Celem, dla którego Synod został zwołany, było uczczenie, potwierdzenie i wdrożenie Soboru"2. Wtedy też padły słowa nietypowe dla tego rodzaju dokumentów: „Synod z głębi serca składa dzięki Bogu Ojcu przez Jego Syna w Duchu Świętym za największą łaskę tego stulecia: za Sobór Watykański II"3.

Jednym z owoców wspólnej refleksji biskupów z całego świata było następujące stwierdzenie: „Eklezjologia «komunii» (communio) jest ideą centralną i podstawową w dokumentach Soboru. Pojęcie koinonia (communio oparte na Piśmie Świętym) w Kościele starożytnym i w Kościołach wschodnich aż po dziś dzień cieszy się wielką czcią. Stąd Sobór Watykański II uczynił wiele, aby Kościół był wyraźniej rozumiany jako «komunia» i bardziej konkretnie jako «komunia» przeżywany"4.

To stwierdzenie pasterzy Kościoła pozwala nam również lepiej zrozumieć kształt dzisiejszej liturgii. Dokonywana reforma była wielkim wysiłkiem zmierzającym w tym kierunku, aby teksty czytań i modlitw, a także kształt całej celebracji wyrażały głębię i różne aspekty prawdy, która kryje się w słowie „komunia”. Niektórzy autorzy uważają, że idąca w tym kierunku reforma liturgii to „kopernikańska zmiana”. Pomaga ona człowiekowi głębiej przeżyć prawdę o obecności Boga pośród nas i o uobecnieniu w konkretnej wspólnocie wierzących zbawczego misterium Chrystusa ${ }^{6}$.

Popatrzmy więc z tej perspektywy na niektóre przynajmniej szczegóły celebracji liturgicznych, w których uczestniczymy w obecnym czasie.

\footnotetext{
${ }^{1}$ Synod obradował w dniach od 25 listopada do 8 grudnia 1985 roku.

${ }^{2}$ Relacja końcowa II Nadzwyczajnego Synodu Biskupów z 1985 roku, I, 2.

${ }^{3}$ Tamże, Zakończenie.

${ }^{4}$ Tamże, II, C, 1.

${ }^{5}$ Por. J. Stefański, Liturgia w odnowie, Gniezno 2000, s. 332.

${ }^{6}$ Por. S. Czerwik, Wprowadzenie do Konstytucji o liturgii świętej, [w:] Sobór Watykański II, Konstytucje, dekrety, deklaracje, Poznań 2002, s. 25-47.
} 


\section{„Communio" jest darem - porządek zstępujący}

Ofiara mszy świętej jest sprawowana przy ołtarzu, a przewodniczy jej kapłan. Dlatego miejsce zajmowane przez kapłana i spełniane przez niego gesty, a także kształt ołtarza i jego usytuowanie należą do głównych znaków, w których wyraża się sposób rozumienia liturgii przez Kościół. W reformie soborowej jeden i drugi znak został inaczej ukształtowany, niż to było dotychczas. Ołtarz został odsunięty od ściany i umieszczony bliżej wiernych, a kapłan, stając za tym ołtarzem, zwraca się twarzą w stronę zgromadzonych ${ }^{7}$.

W liturgii przedsoborowej kapłan wyrażał bardziej obraz Pasterza, który stoi na czele owczarni i prowadzi ją do Boga. W imieniu ludu składa Bogu ofiarę i przez to oddaje Bogu należną cześć. W liturgii posoborowej kapłan przez zwrócenie się twarzą do wiernych wyraża najpierw prawdę, że Syn Boży stał się człowiekiem i jest pośród nas. „Na czele zgromadzenia stoi Chrystus, główny celebrans Eucharystii - czytamy w Katechizmie Kościoła Katolickiego. - Jest On Arcykapłanem Nowego Przymierza. To On niewidzialnie przewodniczy całej celebracji eucharystycznej. Biskup lub prezbiter reprezentuje Chrystusa, działając w osobie Chrystusa-Głowy (in persona Christi Capitis), przewodniczy zgromadzeniu” (KKK 1348).

Te odmienne pozycje, jakie zajmuje kapłan w sprawowaniu Eucharystii - w stronę Boga lub w stronę ludu - wyrażają dwie wielkie tajemnice liturgii. Jedną z nich jest uświęcenie człowieka, a drugą uwielbienie Boga. Choć obydwie są nierozłączne i zawsze występują razem, jak dwie strony tego samego medalu, to jednak trzeba było dokonać wyboru i jedną z tych prawd wyeksponować. Wybrano tę postawę, w której na pierwszy plan wysuwa się uświęcające działania Boga. Wyróżniono ten obraz, który lepiej pokazuje Boga przychodzącego do człowieka i dokonującego dzieła zbawienia. Ikoną tej prawdy jest kapłan, który przychodzi do zgromadzonych uobecniając swoją osobą Chrystusa-Głowę Kościoła, zajmuje wyróżnione miejsce właściwe tylko Chrystusowi i zwraca się twarzą do wiernych.

Znak ten jest wielką pomocą dla uczestników liturgii w dostrzeżeniu tej ważnej prawdy mówiącej o pierwszeństwie działania Bożego przed działaniem człowieka. Żyjący na tym świecie człowiek ma skłonność do zwracania uwagi na to, co on sam czyni, i to niekiedy z wielkim wysiłkiem. Jego wysiłek jest widzialny i odczuwalny, a obecność Boga i Jego działanie po-

${ }^{7}$ „Pożądane jest wystawienie ołtarza wielkiego w takim oddaleniu od ściany, aby go łatwo można obejść i aby celebra mogła się odbywać twarzą do ludu; w świątyni zaś ołtarz powinien zająć takie miejsce, aby rzeczywiście stanowił ośrodek, na którym samorzutnie skupia się uwaga całego zgromadzenia wiernych" (Pierwsza instrukcja o należytym wykonywaniu konstytucji o liturgii świętej Inter oecumenici, nr 91). 
zostaje ukryte za zasłoną znaków. Często więc na pierwsze miejsce w jego przeżyciu wysuwa się to, co on czyni dla Boga, a na plan dalszy schodzą nawet największe dzieła Boże uczynione dla niego. $\mathrm{Z}$ tą naturalną skłonnością dobrze współbrzmiały określenia liturgii podawane przez wielu autorów przed Soborem Watykańskim II. Akcentowały one przede wszystkim to, co czynił człowiek dla Boga. Na pierwszym miejscu był kult sprawowany w Kościele i przez Kościół ${ }^{8}$. Wewnętrznie spójna z tym myśleniem była też postawa kapłana w czasie mszy świętej. Był on zwrócony w stronę ołtarza jako ten, który w imieniu ludu składa Bogu Chrystusową ofiarę.

Nowe akcenty w teologii podkreślające na pierwszym miejscu uświęcające działanie Boga ${ }^{9}$ i Jego troskę o zjednoczenie ludzi wyraziły się również w widzialnym znaku, jakim jest zwrócenie się kapłana twarzą w stronę wiernych. „Chrystus w swym wcieleniu jest Słowem Boga skierowanym do ludzi, w swojej zaś ofierze jest odpowiedzią dawaną przez ludzi Bogu. Odkupienie uobecnione w liturgii jest dlatego wydarzeniem o strukturze dialogowej, której pierwszą fazą jest pośredniczące zstąpienie Syna Bożego jako Słowa Ojca ku ludziom, zaś fazą drugą jest wstąpienie Boga-Człowieka ku Ojcu przez ofiarę. W perspektywie teocentrycznej, powszechnej do Soboru Watykańskiego II, liturgia będąca kultem jest sprawowana na chwałę Boga. W perspektywie antropocentrycznej akcentowanej obecnie, liturgia będąc aktem zbawczym, służy uświęcaniu człowieka"10.

Podobnie możemy rozważyć prawdę o ołtarzu ${ }^{11}$. Kiedy był on zbudowany przy ścianie kościoła, wyrażał czytelnie tajemnicę ofiary, ale nie przypominał stołu uczty. Dlatego kiedyś budowano drugi znak, czyli balaski, które nakrywano specjalnym obrusem i które miały przypominać, że Eucharystia jest także gromadzeniem się przy stole uczty. Dziś, kiedy ołtarz stoi bliżej wiernych i w swoim kształcie przypomina bardziej stół, przeżycia uczestni-

${ }^{8}$ „Liturgia jest zewnętrznym kultem, jaki Kościół oddaje Bogu, albo krócej: zewnętrznym kultem Kościoła" (M. Festugière, Qu'est-ce que la liturgie?, Paris 1914, s. 28-30).

${ }^{9}$ Por. M. Kunzler, Liturgia Kościoła, Poznań 1999 (szczególnie rozdział: Problematyczność pojęcia „kultu”, czyli: po co stużba Boża?), s. 16-25; S. Czerwik, Wprowadzenie do Konstytucji o liturgii świętej, art. cyt., s. 33-38.

${ }^{10}$ W. Świerzawski, Różne rodzaje postugiwania, ale jeden Pan, Kraków 1984, s. 10. Por. także tego autora Mysterium Christi. Chrystus obecny w liturgii $i$ życie chrześcijańskie, Kraków 1975, szczególnie rozdział Próba określenia liturgii, s. 105-114.

${ }^{11}$ Por. Z. Kiernikowski, Symbolika oltarza, „Anamnesis” 46 (2006), s. 27-34; Z. Wit, Ottarz chrześcijański miejscem ofiary i uczty, „Anamnesis” 48 (2007), s. 40-55; tenże, Ottarz $w$ aspekcie teologicznym i liturgicznym, [w:] Ku liturgii nadziei. Ks. dr. Bolesławowi Margańskiemu w sześćdziesiąta piątą rocznicę urodzin, Tarnów 2005, s. 211-230; Leksykon liturgii, opr. B. Nadolski, Poznań 2006, s. 1093-1100; S. M. E. Rosier-Siedlecka, Teologiczna myśl i funkcja poszczególnych elementów wnętrza sakralnego, [w:] Sztuka w liturgii, red. W. Świerzawski, Kraków 1996, s. 89-133 (Misterium Christi, 7). 
ków Eucharystii zbliżyły się do przeżyć apostołów w wieczerniku. Chrystus chciał, aby Jego uczniowie gromadzili się przy stole i w ten sposób przeżywali tajemnicę Jego Ciała, które będzie wydane, i Krwi, która będzie przelana. W dzisiejszym rozumieniu znaku ołtarza jest on „stołem ofiary i uczty, na którym kapłan przedstawiający Chrystusa Pana dokonuje tego samego, co Chrystus uczynił i przekazał swoim uczniom, aby czynili na Jego pamiątkę"12.

Przy tym ołtarzu gromadzą się wierni. Przy nim sprawowana jest zarówno ofiara Chrystusa, jak i spożywany chleb życia. „Teologowie powszechnie uważają, że «ołtarz, który należy do porządku znaku, trzeba uważać za stół uczty Pańskiej. W tym sformułowaniu Ojców Kościoła powinno się zachować całą intensywność teologiczną (synteza pamiątki, obecności i zapowiedzi), a równocześnie charakter intymności. Ołtarz jest prawdziwym stołem, ale jest to stół Pana. Pozwala odnaleźć stół Ostatniej Wieczerzy, ale zarazem antycypuje stół uczty wiecznej». Wobec mocy tego misterium można uznać, że wszystko w kościele ma punkt wyjścia w ołtarzu: ryt i przestrzeń, zgromadzeni wierni”'13.

Lepsze zrozumienie znaku, jakim jest kapłan, a także zatrzymanie się przy znaku ołtarza otwiera nas na inne elementy posoborowej odnowy liturgii. Każdy z nich powinien jak najlepiej służyć świadomemu, czynnemu i owocnemu przeżywaniu misterium, w którym dokonuje się tajemnica zjednoczenia człowieka z Bogiem i ludzi między sobą. Wyróżnione miejsce w tym procesie zajmuje słowo Boże. Soborowa konstytucja Sacrosanctum Concilium uczy, że „Pismo święte ma doniosłe znaczenie w sprawowaniu liturgii. Z niego bowiem pochodzą czytania, które wyjaśnia się w homilii, oraz psalmy przeznaczone do śpiewu. Z niego czerpią natchnienie i ducha prośby, modlitwy i pieśni liturgiczne. W nim też trzeba szukać sensu czynności i znaków. Dlatego w trosce o odnowienie, rozwój i dostosowanie świętej liturgii należy rozbudzać serdeczne i żywe umiłowanie Pisma świętego, o którym świadczy czcigodna tradycja obrządków wschodnich i zachodnich" (nr 24). Zaleca także, aby „szerzej otworzyć skarbiec biblijny i obficiej zastawić wiernym stół słowa Bożego" (nr 51). To właśnie zalecenie stało się jednym z najbardziej widocznych znaków dokonanej odnowy liturgii. Po raz pierwszy w dwutysiącletniej historii Kościoła mamy lekcjonarz mszalny w siedmiu tomach oraz niezwykle bogaty zestaw czytań możliwych do wykorzystania w celebracji innych sakramentów i w sprawowaniu sakramentaliów. Stół słowa Bożego jest rzeczywiście zastawiony bogato jak nigdy dotąd, a „słowo Boże nieustannie głoszone w liturgii jest ciągle żywe i skuteczne dzięki

${ }^{12}$ Obrzęd poświęcenia oltarza, [w:] Obrzędy poświęcenia kościoła i ołtarza, Katowice 2001, s. 117.

${ }^{13}$ S. M. E. Rosier-Siedlecka, Teologiczna myśl i funkcja..., art. cyt., s. 95. 
mocy Ducha Świętego oraz objawia czynną miłość Ojca w niesłabnącej skuteczności w stosunku do ludzi"14. O znaczeniu głoszenia słowa Bożego w liturgii nieustannie przypominają dokumenty Kościoła ${ }^{15}$.

Wśród prawd, które liturgia posoborowa z mocą podkreśla, a które mało jeszcze przeniknęly do świadomości uczestników Eucharystii, jest prawda o przeżywaniu w liturgii tajemnicy zmartwychwstania Chrystusa. Najczęściej przed naszymi oczyma jest krzyż i oczywiście nie może on się zagubić. Przepisy liturgiczne wymagają, aby przy ołtarzu, na którym jest sprawowana Eucharystia, był obecny krzyż. Nie oznacza to, że prawda o zmartwychwstaniu ma zostać zmarginalizowana ${ }^{16}$. Tak niestety często bywało w poprzednich stuleciach. Ks. Wacław Hryniewicz, patrząc z perspektywy roli, jaką teologowie przypisywali prawdzie o zmartwychwstaniu, pisze: „Począwszy od końca średniowiecza nastawionego przede wszystkim na kult cierpiącego człowieczeństwa Chrystusa aż po wiek XX rolą zmartwychwstania Chrystusa w ekonomii zbawienia teologowie zachodni zajmowali się bardzo mało. Całą funkcję zbawczą przypisywano męce i śmierci Chrystusa. Odkupieńcza rola zmartwychwstania oraz chwalebnego panowania Chrystusa (sedet ad dexteram $\mathrm{Pa}$ tris) zostały usunięte w cień. Jeśli czasami wspomniano zmartwychwstanie, to przeważnie w tym celu, aby ukazać w nim osobisty tryumf Chrystusa i chwalebną nagrodę za uniżenie"17. W odnowionej liturgii prawda o zmartwychwstaniu Chrystusa jaśnieje mocniejszym blaskiem. Jest obecna w modlitwach i znakach, uczestnicy Eucharystii wyrażają ją w aklamacji po przeistoczeniu, a także w postawie stojącej, którą Kościół dziś bardziej wyróżnia. Postawa ta jest bowiem rozumiana m.in. jako znak uczestnictwa w zmartwychwstaniu Chrystusa $^{18}$. Ona wyraża godność bytu wolnego, jest postawą ludzi odkupionych, jest postawą „typowo paschalną"19. Na Wschodzie do dziś istnieje zakaz klękania w niedzielę, gdyż jest ona cotygodniową Paschą ${ }^{20}$.

${ }^{14}$ Wprowadzenie teologiczno-pastoralne do lekcjonarza mszalnego, [w:] To czyńcie na moja pamiątkę. Eucharystia w dokumentach Kościoła, Warszawa 1987, nr 4, s. 36.

${ }^{15}$ Por. Instrukcja Eucharisticum misterium z 25 maja 1967, nr 10; Trzecia instrukcja o należytym wykonywaniu konstytucji o świętej liturgii Liturgicae instaurationes z 5 września 1970, nr 2; Instrukcja Inaestimabile donum z 3 kwietnia 1980, nr 1-3; a przede wszystkim Ogólne wprowadzenie do Mszalu rzymskiego z 2002 roku, nr 29, 55-60, 357-362.

${ }^{16}$ Por. M. Bednarz, Spotkanie z Chrystusem Zmartwychwstalym w Jego stowie i Eucharystii, [w:] Ku liturgii nadziei..., dz. cyt., s. 77-100.

${ }^{17}$ W. Hryniewicz, Chrystus nasza Pascha, Lublin 1982, s. 183 (Zarys Chrześcijańskiej Teologii Paschalnej, t. 1).

${ }^{18}$ Por. C. Cibien, Gesti, [w:] Nuovo Dizionario di Liturgia, a cura di D. Sartore e A. M. Triacca, Milano 1988, s. 574.

${ }^{19}$ A. G. Martimort, La Chiesa in pregiera. Introduzione alla Liturgia, t. 1: Principi della Liturgia, Brescia 1987, s. 203.

${ }^{20}$ Por. B. Nadolski, Liturgika, t. 1: Liturgika fundamentalna, Poznań 1989, s. 123. 
Znaki, o których była mowa, przypominają o pierwszeństwie działania Boga w stosunku do działania ludzi i należą do istotnych cech posoborowej odnowy liturgii. Przy takim spojrzeniu na celebrację liturgiczną łatwiej uwolnić się od przeżywania jej tylko jako obowiązku czy przykazania ${ }^{21}$. Łatwiej także otworzyć się na Tego, który był, który jest i który ciągle przychodzi do swego Kościoła (por. Ap 1, 4).

\section{„Communio" jest zadaniem - porządek wstępujacy}

„Communio”, które jest przede wszystkim darem Boga, jest również zadaniem, które Bóg ludziom powierza. W liturgii przeżywamy również ten wymiar tajemnicy jedności. Wysiłek twórców odnowy liturgii szedł także w kierunku takiego jej ukształtowania, aby wszyscy wierni mogli w sposób bardziej świadomy, czynny i owocny uczestniczyć w liturgii, szczególnie eucharystycznej. Chodzi tu o pastoralny charakter odnowy liturgicznej, o dojrzałe uczestnictwo wiernych. Niektórzy liturgiści uważają, że „głównym rysem liturgicznej odnowy jest jej duszpasterski charakter"22.

Jest bardzo wiele szczegółów dotyczących tej problematyki. Najpierw trzeba zwrócić uwagę na język. Mimo niewątpliwych walorów języka łacińskiego, który dominował w liturgii przez całe wieki, Kościół uznał, że każda wspólnota może zwracać się do Boga w tym języku, którym się na co dzień posługuje. Jego wprowadzenie zaleca soborowa konstytucja o liturgii (por. nr 63), a szczegółowe normy określały kolejne dokumenty odnowy liturgicznej ${ }^{23}$. Po kilku latach od wprowadzenia języków narodowych do liturgii i innych elementów odnowy widać było pozytywne skutki podjętych decyzji. „Święta Kongregacja Sakramentów i Kultu Bożego z zadowoleniem stwierdza rozliczne i dodatnie skutki reformy liturgicznej: bardziej czynne i bardziej świadome uczestnictwo wiernych w tajemnicach liturgicznych, wzbogacenie zasobu wiadomości doktrynalnych i katechetycznych dzięki używaniu języków rodzimych i bogactwu czytań biblijnych, wzrost poczucia wspólnoty w życiu liturgicznym, uwieńczone powodzeniem wysiłki zmierzające do usuwania rozdźwięku pomiędzy życiem a kultem, pomiędzy pobożnością liturgiczną a pobożnością osobistą, pomiędzy liturgią a pobożnością ludową"24.

${ }^{21}$ Por. J. Stefański, Liturgia w odnowie..., dz. cyt. s. 332.

${ }^{22}$ S. Koperek, Rys historyczny liturgii mszalnej, [w:] Msza święta, pod red. W. Świerzawskiego, Kraków 1992, s. 60.

${ }^{23}$ Zagadnienie wprowadzania języków narodowych do liturgii omawia szerzej ks. Stanisław Czerwik we Wprowadzeniu do Konstytucji o liturgii świętej..., dz. cyt. s. 29-30.

${ }^{24}$ Instrukcja Inaestimabile donum z 17 kwietnia 1980, Wprowadzenie. 
W dojrzałym i czynnym uczestnictwie wiernych pomaga także przywrócona do liturgii modlitwa powszechna ${ }^{25}$ oraz procesja $\mathrm{z}$ darami ${ }^{26}$. W modlitwie wierni kierują do Boga prośby w różnych intencjach, a w procesji z darami przynoszą na ołtarz owoc ziemi i swojej pracy.

Wśród cech charakterystycznych celebracji liturgii po Soborze Watykańskim II trzeba wymienić również zaproszenie wiernych świeckich do spełniania funkcji liturgicznych. W okresie przedsoborowym, jeśli wierny świecki przeczytał jakąś modlitwę lub fragment słowa Bożego, kapłan musiał to powtórzyć. Czynność spełniona przez osobę, która nie miała święceń, była uznawana tylko za pomocniczą. Zasady te zmienia już pierwsza instrukcja o należytym wykonaniu konstytucji o liturgii. Czytamy w niej, że „tekstów należących do chóru albo do ludu a przez nich śpiewanych lub recytowanych celebrans nie powtarza prywatnie. Podobnie celebrans nie czyta prywatnie tych lekcji, które czyta lub śpiewa odpowiednia osoba"27.

Zmiana w tej dziedzinie jest bardzo wielka. Soborowa konstytucja o liturgii poświęca tej sprawie kilka punktów. Najpierw wskazuje ogólną zasadę, która mówi, że „czynności liturgiczne nie są prywatnymi czynnościami, lecz uroczyście sprawowanymi obrzędami Kościoła, który jest «sakramentem jedności», czyli ludem świętym, zjednoczonym i zorganizowanym pod zwierzchnictwem biskupów. Dlatego czynności liturgiczne należą do całego Ciała Kościoła, uwidaczniają je i na nie oddziałują. Poszczególnych natomiast członków dotyczą w różny sposób, stosownie do różnorodności stanów, zadań i czynnego uczestniczenia” (nr 26). Konstytucja podaje też bardziej szczegółowe wskazania, które wpływają na kształt celebracji liturgicznych: „W sprawowaniu liturgii każdy, kto wykonuje swą funkcję - czy to duchowny, czy wierny świecki - powinien w pełni wykonywać wyłącznie tylko to, co należy do niego z natury rzeczy i na podstawie przepisów liturgicznych. Ministranci, lektorzy, komentatorzy i członkowie chóru również spełniają prawdziwą posługę liturgiczną. Niech więc wykonują swoją funkcję z tak szczerą pobożnością i dokładnością, jak to przystoi wzniosłej służbie i odpowiada słusznym wymaganiom Ludu Bożego" (nr 28-29).

Zagadnienie posługiwania wiernych świeckich w liturgii jest dziś obecne w podręcznikach liturgiki ${ }^{28}$, w refleksji teologicznej ${ }^{29}$ i w życiu Kościoła.

${ }^{25}$ Por. Ogólne wprowadzenie do Mszału rzymskiego, nr 69-71.

${ }^{26}$ Por. tamże, nr 73-74.

${ }^{27}$ Instrukcja Inter oecumenici z 26 września 1964, nr 32-33.

${ }^{28}$ Por. B. Nadolski, Liturgika, dz. cyt., t. 1, s. 91-128; T. Sinka, Zarys liturgiki, Kraków 1994, s. 20-27; tenże, Podzial funkcji w zgromadzeniu liturgicznym, [w:] Msza święta, dz. cyt., s. 170-191; A.-J. Znak, Fundamentalne rzeczywistości liturgii, Oleśnica 1992, s. 74-88. 231-248.

${ }^{29}$ Por. B. Margański, Uczestnictwo wiernych $w$ liturgii Kościoła $w$ duchu konstytucji Sacrosanctum Concilium, [w:] Euntes docete, red. S. Koperek, Kraków 1993, s. 90-102; A. Dyr, 
W Polsce szczególną rolę we wprowadzeniu tych zaleceń soborowych w życie Kościoła miał sługa Boży ks. Franciszek Blachnicki i kierowane przez niego w latach 1967-1980 Krajowe Duszpasterstwo Służby Liturgicznej30. Do podejmowania przez wiernych świeckich funkcji liturgicznych zachęcają biskupi: „Zgodnie z OWMR 91 wierni świeccy po odpowiednim przygotowaniu powinni spełniać w liturgii wszystkie funkcje, które są dla nich przeznaczone, a więc czytać słowo Boże z wyjątkiem Ewangelii, śpiewać psalm responsoryjny i werset przed Ewangelią, odczytywać wezwania modlitwy powszechnej oraz komentarze, posługiwać przy ołtarzu i przy miejscu przewodniczenia, troszcząc się o mszał, kielich i patenę, kadzidło i krzyż, światło i wodę. Oni także powinni przynosić do ołtarza chleb i wino jako dary ludu Bożego, zbierać składkę, pełnić funkcję kantora lub organisty, ożywiać śpiew zgromadzenia i wykonywać niektóre śpiewy jako schola lub chór. Nadzwyczajni szafarze Komunii świętej mogą zgodnie z prawem pomagać w udzielaniu Komunii świętej i zanosić ją chorym"31.

W ten sposób coraz bardziej kształtuje się świadomość wspólnotowego sposobu celebracji liturgii, o którym mówi Katechizm Kościoła Katolickiego: „Liturgię celebruje cała wspólnota, Ciało Chrystusa zjednoczone ze swoją Głową” (nr 1140); „W celebracji sakramentów całe zgromadzenie jest więc «liturgiem», każdy według swojej funkcji, ale «w jedności Ducha», który działa we wszystkich" (nr 1144) ${ }^{32}$.

Dziś Kościół uczy, że lektor spełnia w liturgii swoją własną funkcję ${ }^{33}$. Jeśli lekcję czyta kapłan, dzieje się to na zasadzie zastępstwa. Podobnie jest z innymi funkcjami, które Kościół w liturgii powierza wiernym świeckim. Funkcje te nie są rozumiane jako pomoc kapłanowi, lecz jako własne czynności poszczególnych osób i zespołów. Choć od czasu Soboru Watykańskiego II wielu wiernych świeckich podjęło różne funkcje liturgiczne,

Postugiwanie świeckich w Kościele, „Communio” 3 (1997), s. 112-128; H. Sobeczko, Postawy wewnętrzne i zewnętrzne w czynnym uczestnictwie wiernych we Mszy świętej, „Ruch Biblijny i Liturgiczny” 42 (1989), s. 207-224; S. Szczepaniec, Stużba liturgiczna. Założenia, cele i program formacji, [w:] Gorliwy apostot wewnętrznej odnowy człowieka. Materiały z sympozjum poświęconego Założycielowi Ruchu Światto-Życie, Lublin, 5-6 października 1987 r., Światło-Życie 1988, s. 106-116; tenże, Postugiwanie świeckich w liturgii, „Roczniki Teologiczne” 48 (2001) z. 8, s. 113-137.

${ }^{30}$ Por. S. Szczepaniec, Postuga Krajowego Duszpasterstwa Stużby Liturgicznej, „Liturgia Sacra" 3-4 (1995), s. 145-152.

${ }^{31}$ Wskazania Episkopatu Polski po ogłoszeniu nowego wydania OWMR z 9 marca 2005, nr 52.

${ }^{32}$ Por. S. Czerwik, Wprowadzenie do Konstytucji o liturgii świętej..., art. cyt., 38-40; tenże, Pojęcie i natura liturgii, [w:] Euntes docete, dz. cyt., s. 41-59; S. Szczepaniec, Liturgię celebruje cała wspólnota - cz. I, „Liturgia Sacra” 1-2 (1996), s. 71-78; tenże, Liturgię celebruje cała wspólnota - cz. II, „Liturgia Sacra” 3-4 (1996), s. 63-74.

${ }^{33}$ Por. Ogólne wprowadzenie do Mszału rzymskiego, nr 99. 
to jednak trzeba przyznać, że jest jeszcze wiele do zrobienia. Nie wszystkie talenty i charyzmaty, którymi Bóg obdarzył mężczyzn i kobiety, przyczyniają się do objawienia piękna i głębi tajemnicy, którą przeżywamy w liturgii. By tak się stało, trzeba wspólnej troski kapłanów i świeckich.

Kształt liturgii sprawowanej przez Kościół po Soborze Watykańskim II zmienił się w wielu zewnętrznych szczegółach. Zmiana miała służyć bardziej świadomemu, czynnemu i owocnemu uczestnictwu wiernych w świętych obrzędach, szczególnie zaś przeżywaniu tajemnicy komunii, której sprawcą jest Duch Święty. Katechizm Kościoła Katolickiego uczy, że „celem posłania Ducha Świętego w każdej czynności liturgicznej jest doprowadzenie do komunii z Chrystusem, by formować Jego Ciało. Duch Święty jest jak sok winnego krzewu Ojca; przynosi on swój owoc w latoroślach. W liturgii urzeczywistnia się najbardziej wewnętrzne współdziałanie Ducha Świętego i Kościoła” (nr 1108).

Ojciec Swięty Jan Paweł II w 40. rocznicę ogłoszenia soborowej konstytucji o liturgii zwraca uwagę na to, że odnowa liturgiczna znalazła najbardziej widoczny wyraz w publikacji ksiąg liturgicznych ${ }^{34}$. Zwraca też uwagę na konieczność formacji liturgicznej: „W tej perspektywie bardziej niż kiedykolwiek konieczne jest pogłębienie życia liturgicznego w naszych wspólnotach poprzez odpowiednia formację pasterzy i wszystkich wiernych, tak aby - zgodnie z życzeniem wyrażonym przez Sobór - uczestnictwo w obrzędach liturgicznych było pełne, świadome i czynne. Potrzebne jest zatem duszpasterstwo liturgiczne prowadzone w całkowitej wierności nowym Obrzędom. Dzięki nim udało się wzbudzić zainteresowanie słowem Bożym zgodnie ze wskazaniami Soboru, który zalecał wprowadzenie «dłuższego, bardziej urozmaiconego i lepiej dobranego czytania Pisma Świętego». Nowe lekcjonarze, na przykład, zawierają szeroki wybór fragmentów biblijnych, stanowiąc niewyczerpane źródło, z którego Lud Boży może i powinien czerpać. Nie możemy bowiem zapomnieć, że «słuchanie Słowa Bożego przyczynia się do budowania i wzrostu Kościoła, a godne podziwu dzieła, jakich Bóg na różne sposoby dokonał niegdyś w historii zbawienia, prawdziwie uobecniają się w sposób mistyczny w znakach liturgii». W celebracji liturgicznej słowo Boże w pełni wyraża swe znaczenie, pobudzając chrześcijan do ciąłej odnowy swego życia, tak aby «słowa usłyszane w czynności liturgicznej znalazły również pokrycie w życiu»"35.

Kraków

KS. STANISEAW SZCZEPANIEC

\footnotetext{
${ }^{34}$ List apostolski Spiritus et Sponsa, nr 7.

${ }^{35}$ Tamże, nr 8.
} 


\section{Słowa kluczowe}

Liturgia, odnowa liturgii, communio, ołtarz, posługi świeckich w liturgii

\section{Summary}

\section{Liturgical Celebration after the Second Vatican Council}

This article attempts to approach the shape of the liturgy after the Second Vatican Council from the perspective of communio. The author presents various elements of the contemporary liturgical celebrations which help to experience the liturgy in a deeper way. He speaks about the altar, the priest, the active engagement of the participating community and also about other details of the celebration, owing to which the faithful can be united in the salvific mystery provided by God in the liturgy.

\section{Keywords}

Liturgy, renewal of the liturgy, communio, altar, lay ministries in the liturgy 